\title{
Isolation and Identification of Bacteria in Subclinical Mastitis and Effect on Composition of Buffalo Milk
}

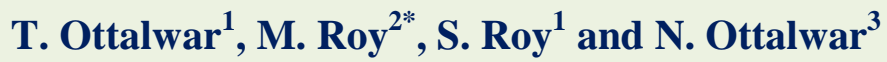 \\ ${ }^{1}$ Department of Veterinary Medicine, College of Veterinary Science \& A. H., Anjora, \\ Durg, Chhattisgarh, India \\ ${ }^{2}$ Department of Veterinary physiology and Biochemistry, College of Veterinary Science \& \\ A.H., Durg, Chhattisgarh, India \\ ${ }^{3}$ Department of Veterinary Parasitology, College of Veterinary Science \& A. H., Anjora, \\ Durg, Chhattisgarh, India \\ *Corresponding author
}

\section{A B S T R A C T}

\section{Keywords}

Subclinical, Mastits, Buffalo, Milk,

Composition,

Bacteria

\section{Article Info}

Accepted:

26 January 2018

Available Online:

10 February 2018
An investigation was carried out to determine the commonly occurring subclinical mastitis pathogens and the relationship between chemical parameters of milk. A total of 1650 milk samples from buffaloes of different dairy farm were randomly screened for prevalence of subclinical mastitis by indirect test like Somatic Cell Count (SCC). The SCC of individual quarter milk samples increased significantly $(\mathrm{P}<0.01) 1.52$ to $3.98 \times 10^{5}$ cells as compared $1.00 \times 10^{5}$ cells in per ml milk. A direct correlation was established between elevated SCC and quality of milk was established. Significant $(\mathrm{p}<0.05)$ elevated levels of protein $\%$ and sodium ion concentration whereas non-significant increase of $\mathrm{pH}$ was recorded with increased SCC in milk samples. Significant decrease in milk fat $\%$, lactose $\%$ and Potassium ion concentration was recorded in infected animals. The occurrence of major etiological agent in the study was Staphylococcus spp. with occurrence rate of $41.51 \%$.

\section{Introduction}

Mastitis has been recognized as one of the major problem in dairy animals which results in great economic losses to the farmers due to reduced productivity, milk quality and cost of treatment. Bovine Clinical and subclinical mastitis (SCM) is the inflammatory reaction of mammary gland parenchyma, regardless of the cause, characterized by physical, chemical and usually bacterial changes in milk and pathological changes in the glandular glands
(Radostitis, 2010). Milk is the staple diet and is one of the most important foods of humans and animals. It is considered as a complete diet due to its essential components (Battaglia, 2007; Javaid et al., 2009). Mastitis is caused by different microorganisms like several species of bacteria, fungi, mycoplasma and also with environmental factors and is recognized by decreased milk production with altered composition of milk. Somatic cell count (SCC) in milk is used as an indicator to monitor the degree of the udder health and 
changes occur concomitantly when the gland is colonized by microorganisms. Increase in SCC is widely accepted as an early emergence of inflammatory changes of mammary gland (Tahawy and Far, 2010).

Reduced milk yield may occur as a result of damage caused by bacteria to milk secretary epithelia of mammary gland (Juliano et al., 2016). Subclinical infections are those for which no visible changes occur in the appearance of milk or the udder, but milk production. Early identification of the condition is essential not only for the welfare of animal but also for dairy farmers and veterinarians. Therefore, the present study was conducted for the screening of microbial etiology and to assess the impact of mastitis on chemical composition of buffalo milk in different districts of Chhattisgarh State of India.

\section{Materials and Methods}

About 50-60 ml of milk sample was collected from apparently healthy buffaloes of Murrah breed from dairy farms basis of history of sudden drop in milk yield in and around Durg, Rajnandgaon, Raipur and Bilaspur districts of Chhattisgarh state after proper disinfection of teat surface with $70 \%$ ethanol and discarding few strips of fore-milk and yield and confirmed diagnosis was made by somatic cell count performed on spot at dairy farms.

In SCM the most significant abnormality of the milk is the increase in SCC. A total of $\mathrm{SCC}>200000$ cell $/ \mathrm{ml}$ of milk is an indicator, for intra mammary infection in case of lactating dairy crossbred cows (Singh and Ludri, 2001). Somatic cell count was performed using the instrument the Porta SCC milk test, procured from the Porta Check. Milk parameters like $\mathrm{pH}$, Lactose (\%), Fat $(\%)$, Solid Not Fat (\%), Protein (\%), Freezing point $\left({ }^{0} \mathrm{C}\right)$ was estimated by using Milk analyzer (Funke Gerber, Lactostar). Milk electrolyte contents ( $\mathrm{Na} \& \mathrm{~K}$ ) was determined using Flame photometer (Systonic) and results were expressed in $\mathrm{mg} / \mathrm{dL}$.

\section{Isolation and identification of bacteria}

Milk samples were subjected to isolation and identification of bacteria on the basis of cultural, morphology and biochemical characteristics (Buchman and Gibbon, 1984). Bacteriological investigations on milk samples were undertaken to isolate and identify bacteria associated with subclinical mastitis in cows. A loopful of each milk sample was streaked on $5 \%$ blood agar plates and incubated at $37^{\circ} \mathrm{C}$ for $24 \mathrm{hrs}$. After $24 \mathrm{hrs}$, the plates were examined for colonial morphology, presence of one or more colonies, profuseness of growth colony and hemolysis. Further, the milk samples were also inoculated into nutrient agar, cetrimide agar, Mac Conkey agar and incubated at $37^{\circ} \mathrm{C}$ for 24 hours for identification of Escherichia coli. Pink, round, translucent and convex colonies about $2 \mathrm{~mm}$ in diameter from Mac Conkey's agar were picked up and streaked on Eosine methylene blue (EMB) agar. The metallic lusture in reflected light were suspected for $E$. coli. The colonies were picked up stored at $4^{\circ} \mathrm{C}$ for further confirmation with biochemical characteristics, cultures were subjected to primary biochemical tests viz. Indole production test, methyl red, citrate utilization, Vogesproskauer test, Catalase test, Oxidase test, reactions as suggested by Edwards and Ewing (1972).

\section{Statistical analysis}

The mean and standard error of the recorded value was calculated. The data was analyzed statistically by ANOVA method using One way analysis of variance followed by DMRT (Duncan's multiple range test) (Snedeor and Cochran, 1994). 


\section{Results and Discussion}

A total of 1650 milk samples from buffaloes were collected from different districts of Chhattisgarh State and 685 were screened positive for subclinical mastitis. On the basis of SCC of milk the data revealed lower prevalence percentage $(41.51 \%)$ as compared to the studies of Iragua et al., (2015). The SCC levels were significantly influenced by quarter health status.

The SCC of individual infected quarter milk samples increased significantly $(\mathrm{P}<0.01)$ from 1.52 to $3.98 \times 10^{5}$ cells as compared $1.00 \times 10^{5}$ cells in per $\mathrm{ml}$ of normal milk. An elevated SCC in milk has a negative influence on the quality of raw milk Sharma et al., (2011)

\section{Alterations in milk composition}

Data presented in Table 1 concluded the significant $(p<0.05)$ increased concentration of protein in milk samples of infected animals.

It is often accepted that during mastitis, there is an increase in milk proteins that has been due to the influx of blood-borne proteins like serum albumin (major blood protein), minor serum proteins and immunoglobulins, $\alpha-$ macroglobulin (Aldist et al., 1995)) into the milk coupled with a reduced casein protein in milk (Muhee et al., 2017).

A positive correlation between SCC and fat \%, exists in samples from infected buffaloes. Fat percentage analyzed in milk samples showed significant $\quad(\mathrm{P}<0.05)$ increased levels in subclinical cases as compared to normal milk of buffaloes.

The result of the current study in fat concentration was according to the findings of Sharif and Muhammad (2008). According to Bruckmaier et al., (2004) the increase in fat concentration is an indicative of reduced lactose synthesis and therefore reduced milk volume while the fat synthesis is only slightly depressed. In contrary to our findings Alemu et al., (2013) described mastitis as a cause for decrease in fat composition.

Our findings of reduced SNF \% of milk in sub clinical mastitis are in agreement with Reis $e t$ al., (2013).

The decrease in SNF content of milk in mastitis is attributed to changes in vascular permeability due to the inflammatory process and the damage of epithelial cells responsible for the synthesis of milk components as well as changes in the enzymatic action of somatic cells or microorganisms in the infected mammary gland (Muhee et al., (2017).

Significant reduced concentration of Lactose content was observed in the present study. Furthermore it was recorded that many of the common mastitis-causing organisms are capable of fermenting lactose.

The lower concentrations of lactose in mastitic milk may be partly due to the activities of these organisms (Auldist et al., 1995).

The decline in milk lactose $\%$ in affected quarters might be due to the damage to the alveolar epithelial cells.

The reduced lactose concentrations are unlikely to be due to reduced synthesis and secretion at the cellular level and can only be depressed and there is an increased influx of electrolytes during mastitis.

The more likely reason for depressed lactose concentrations is the leakage of lactose out of milk via the paracellular pathways that proliferate during mastitis. Therefore, the low lactose concentrations are dependent on the severity of damage to the tight junctions (Bruckmaier, 2004). 
Table.1 Biochemical alterations in subclinical mastitis milk

\begin{tabular}{|l|l|l|}
\hline Parameters & Healthy & Infected \\
\hline Fat \% & $6.868 \pm 0.08^{\mathrm{b}}$ & $8.828 \pm 0.14^{\mathrm{a}}$ \\
\hline Lactose \% & $5.187 \pm 0.46^{\mathrm{a}}$ & $4.696 \pm 0.91^{\mathrm{a}}$ \\
\hline Protein & $4.508 \pm .08^{\mathrm{b}}$ & $5.036 \pm .04^{\mathrm{a}}$ \\
\hline SNF \% & $9.325 \pm .05^{\mathrm{b}}$ & $8.426 \pm 0.17^{\mathrm{a}}$ \\
\hline pH & $6.566 \pm .04^{\mathrm{a}}$ & $6.776 \pm .05^{\mathrm{a}}$ \\
\hline Sodium $(\mathrm{mg} / \mathrm{dl})$ & $106 \pm 8.34^{\mathrm{a}}$ & $156 \pm 12.57^{\mathrm{b}}$ \\
\hline Potassium & $138 \pm 10.21^{\mathrm{a}}$ & $114 \pm 13.55^{\mathrm{b}}$ \\
\hline
\end{tabular}

Mean \pm SEM with different superscripts $a, b$ within rows differ significantly at $\mathrm{P}<0.05$.

Table.2 Bacterial organisms isolated from cases of SCM in Buffaloes

\begin{tabular}{|l|l|l|}
\hline Species of organism isolated & No. of Positive Samples & Percentage \\
\hline Staphylococcus aureus & 27 & 39.71 \\
\hline Escherichia Coli & 17 & 25 \\
\hline Streptococcus spp. & 14 & 20.59 \\
\hline Pseudomonas aurigenosa & 08 & 11.76 \\
\hline Proteus & 02 & 2.94 \\
\hline
\end{tabular}

Table.3 Biochemical properties of bacteria isolated from bubaline subclinical milk mastitis milk

\begin{tabular}{|l|l|l|l|l|l|l|}
\hline S.No & Biochemical test & E.Coli & Staph.aureus & $\begin{array}{l}\text { Streptococcus } \\
\text { spp }\end{array}$ & $\begin{array}{l}\text { Pseud. } \\
\text { aeruginosa }\end{array}$ & $\begin{array}{l}\text { Proteus } \\
\text { spp }\end{array}$ \\
\hline 1. & Indol production & + & - & - & - & - \\
\hline 2. & Methyl red & + & + & + & - & + \\
\hline 3. & Vogesproskauer & - & + & + & - & - \\
\hline 4. & Citrate utilization & - & + & NA & + & + \\
\hline 5. & Catalase test & + & + & - & + & + \\
\hline 6. & Oxidase test & - & - & - & + & - \\
\hline
\end{tabular}

$\mathrm{NA}=$ Not applicable

Evaluation of $\mathrm{Na}^{+}$and $\mathrm{K}^{+}$concentrations from milk samples of dairy cows with sub clinical mastitis can be of immense diagnostic benefit. The ionic content of milk varies markedly from that of extracellular fluid which batches the acini of the mammary gland. Milk contains a high concentration of potassium relative to sodium (Aldist, 1998). Present study revealed significant $(\mathrm{p}<0.05)$ increased sodium concentration whereas decrease potassium concentration in milk samples of animals infected with subclinical mastitis.
The concentrations of some minerals altered during subclinical mastitis, and can play important role in determining the milk quality. Potassium, the most abundant mineral in milk, leaks out of the milk where as significant increase concentration of sodium was observed in infested cases. In blood sodium concentration is more so it leaks into the milk increasing concentrations above normal (Ambade et al., 2012, haron et al., 2014). Damage to the epithelial tissue increase in permeability of the "paracellular" 
junctions allows more $\mathrm{Na}+$ to diffuse into the mammary gland, resulting in an increase in milk $\mathrm{Na}+$ concentration, milk potassium concentration declines, proportionally less than $\mathrm{Na}$ (Guha and Gera, 2011)

The $\mathrm{pH}$ was significantly higher in the subclinical mastitic milk than in the normal ones $(\mathrm{P}<0.05)$. A study by Ambade et al., (2012) also stated that there was a significant increase in the $\mathrm{pH}$ of milk with clinical and subclinical mastitis.

The charges on reduced secretory activities on mammary cells might lead to variation in $\mathrm{pH}$ level (Ongole et al., 2007). Fundamentally elevation in SCC and decline in $\mathrm{pH}$ cause to increase acidity of milk.

\section{Isolation and Identification of bacteria}

Our research also investigated pathogens involved in mastitis (Table 2). A total of 78 isolates were obtained from cows and among the various bacteria isolated, Staphylococcus spp. occupied prime position with occurrence rate of $39.71 \%$ However, other bacteria isolated include Streptococcus spp. (20.59\%), E. coli (25\%), (1.282\%) Pseudomonas aeruginosa (11.76\%) and Proteus spp. $(2.94 \%)$. The findings of present study are in close confirmation with the earlier report of Singh et al., (2016) and Demme and Abegaz, 2015. The highest occurrence was registered by Staphylococcus.

Biochemical testing is based on the metabolic activities of bacteria. Sustained appereance of bubble in catalase test confirms the presence of Staphylococcus species and also positive coagulase test. Clear to Blue dark colour produce in oxidase test confirms presence of Pseudomonas species. Development of bright red color at the interface of the reagent and the broth is indicative of E coli and Proteus spp. (Table 3).
As buffalo milk is the most preferred main components of the diet of the rural society as well as urban and is consumed in the raw state by community. Early detection of subclinical mastitis by SCC and alterations in milk composition helps to determine the milk quality. The presence and consumption of milk from infected animals may pose a public health hazard in addition to the reduced milk quality due to mastitis in buffaloes.

\section{References}

Alemu, S., Tamiru, F., Almaw, G. and Tsega, A. 2013. Study on bovine mastitis and its effect on chemical composition of milk in and around Gondar Town, Ethiopia. J. of Vet. Med. Animal health. 5(8): 215-221.

Ambade, R.B., Bonde, S.W. and Takarkhede, R.C. 2012. Cellular and biochemical indicators of bovine subclinical mastitis. Anim. Science papers and Report. 6(1):3-7.

Auldist, M.J. and Hubble, I.B. 1998. Effects of mastitis on raw milk and dairy products. Austra. J. Dairy Technol. 53: 28-36.

Auldist, M.J., Coats, S., Rogers, G.L., and McDowell, G.H. 1995. Changes in the composition of milk from healthy and mastitis dairy cows during the lactation cycle. Austra. J. Exp. Agri.. 35:427-436.

Battaglia, R.A. 2007. Handbook of Livestock Management. Pearson Prentice Hall, New Jersey, pp. 210-211.

Bruckmaier R.M., O., C.E. and Blum, J.W. 2004. Fractionized milk composition in dairy cows with subclinical mastitis. Vet. Med.Czech. 8(283-290).

Buchman, R.E. and Gibbon, N.E. 1984. Bergey's Manual of determinative Bacteriology. $8^{\text {th }}$ Edn. Williams and Wilkins Company, Baltimore, USA.

Demme, B. and Abegaz, S. 2015. Isolation and Identification of Major Bacterial Pathogen from Clinical Mastitis Cow Raw Milk in Addis Ababa, Ethiopia. Acad. J. Ani. Dis. 4(1): 44-51.

Edwards, P.R. and Ewing, W.H. 1972. Identification of enterobacteriacae, $3^{\text {rd }}$ Edn. Burgus, Minneapolis.

Guha, A. and Gera, S. 2012. Evaluation of 
chemical and electrolyte components of milk in subclinical mastitis in Holstein $X$ Haryana cattle. Explo. Ani. Med. Res. 1(2): 140-143.

Haron, A.W., Abdullah, F.F.J., Tijjani. A., Abba, Y., Adamu, L., Mohammed, K., Amir, A.M.M., Sadiq, M.A. and Lila, M.A.M. 2014 The use of Natand K+ion concentrations as potential diagnostic indicators of subclinical mastitis in dairy cows, Vet. World. 7(11): 966-969

Iraguha, B., Hamudikuwanda, H. and Mushonga, B. 2015. Bovine mastitis prevalence and associated risk factors in dairy cows in Nyagatare District, Rwanda. J. South Afri. Vet. Asso. 86(1), 1228-1233.

Javaid, S.B., Gadahi, J.A., Khaskeli, M., Bhutto, M.B., Kumbher, S. and Panhwar, A.H. 2009. Physical and chemical quality of market milk sold at Tandojam, Pakistan. Pak. Vet. J. 29:27-31.

Juliano, L., Goncalves, Cristian M. de M. R. Martins, Barreiro1, J.R. and Tomazi, T. Gameir, A, H., Kamphuis, C., Hogeveen, H. and Santos, M.V.D. 2016. Effect of Bovine Subclinical Mastitis on Milk Yield and Composition at the Mammary Quarter Level. NMC Annual Meeting Proceedings.

Muhee, A., Malik, H.U., Asharaf, I., Shah, O.S. Jan, A., Rather, M.W. and Showkeen Muzamil. 2017. Biochemical and Mineral Alterations of Milk Chemistry in Mastitis. Int. J. Curr. Microbiol. Appl. Sci. 6(7): 4591-4594.

Ongola, H., Shitandi, A. and Nanua, J. 2007. Effect of mastitis on raw milm compositional quality. J. Vet. Sci. 8: 237242.

Radostitis, O.M., Gay, C.C., Hinchcliff, K.W. and
Constable, P.D. 2010. Veterinary Medicine: A textbook of the diseases of cattle, horse, sheep, pig and goats. $10^{\text {th }}$ Edn. W.B. Saunders Co. Ltd., Philadelphia. pp 673762.

Reis, C.B.M., Barreiro, J.R., Mestieri, L., Porcionato, M.A.F. and santos, M.V. 2013. Effect of somatic cell count and mastitis pathogens on milk composition in Gyr cows, BMC Vet Res. 9:67-75.

Sharif, A. and Muhammad, G. 2008. Somatic cell count as an indicator of udder health status under modern dairy production [a review] Pak. Vet. J. 28:194-200.

Sharma, N., Singh, K. and Bhadwal, M.S. 2011. Relationship of Somatic Cell Count and Mastitis: An Overview. Asian-Austra. J. Ani. Sci.. 24(3):429-438.

Shuster, D.E., et al., Suppression of Milk Production during Endotoxin-Induced Mastitis. J. Dairy Sci., 1991. 74(11): p. 3763-3774.

Singh, M. and Ludri, R.S. 2001. Somatic cell counts in Murrah buffaloes (Bubalus bubalis) during different stages of lactation, parity and season. Asian -Australian. J. Ani. Sci. 14:189-192.

Singh, N., Singh, P., Patel, R.K. 2016. Isolation and identification of bacterial organisms from mastitic milk. J. Livestock Sci. 7: 4648.

Snedecor, G.W. and Cochran, W.G. 1994. Statistical methods (8th eds). Affiliated East-West Press, New Delhi: Affiliated East-West Press; 1994

Tahawy, A.S. and Far, A.H. 2010. Influences of somatic cell count on milk composition and dairy farm profitability. Int. J. Dairy Technol. 63:463-469.

\section{How to cite this article:}

Ottalwar, T., M. Roy, S. Roy and Ottalwar, N. 2018. Isolation and Identification of Bacteria in Subclinical Mastitis and Effect on Composition of Buffalo Milk. Int.J.Curr.Microbiol.App.Sci. 7(02): 3124-3129. doi: https://doi.org/10.20546/ijcmas.2018.702.376 